\section{Deprescribing in polypharmacy: a process to evaluate, question and terminate drug treatment in the elderly}

Tommy Eriksson

The key to rational drug therapy is to continuously evaluate and appraise medications prescribed for an individual patient. This is especially important for elderly patients who may have multiple diseases and many medicines. Ongoing evaluation of the potential and real benefit as well as harms (problems) of medication taken by the patients is fundamental to the pharmacist's provision of pharmaceutical care. Curative and short-term emergency treatments such as antibiotics are probably not the major problem. More focus is needed on preventive treatments and on medicines with doubtful or no approved indication for the treatment. Symptom relief drugs with uncertain or poor evidence of clinical benefit must also be evaluated. Table $1 \mathrm{can}$ be used as a tool for this assessment. ${ }^{1}$

If there is a reason to end or pause a drug treatment this must be done gently to avoid problems for the patient. When deprescribing, one must consider the cessation of interaction-related effects mainly on metabolism, the risk of acute events and that the illness or symptoms return. There can also be specific problems related to the pharmacological properties of the drug, disease or symptom, or a combination of these. These may include rebound effects, withdrawal symptoms or both. Rebound effects include physiological compensation that provides transient symptom reinforcement and can last for days to months. Examples of this include severe high blood pressure when a betablocker is stopped and increased acid production in the stomach when proton pump inhibitors are terminated. Withdrawal reactions can be strong and interpreted by the patient and care as disease recurrence. This has been reported for many classes of drugs such as serotonin

Correspondence to Dr Tommy Eriksson, Department of Clinical Pharmacology, Laboratory Medicine, Lund University, Lunds universitet box 188, Lund 22100 , Sweden; tommy.eriksson@mah.se

\begin{tabular}{|c|c|c|c|}
\hline & $\begin{array}{l}\text { With clear } \\
\text { benefit }\end{array}$ & $\begin{array}{l}\text { Unclear } \\
\text { benefit }\end{array}$ & $\begin{array}{l}\text { Do not } \\
\text { benefit }\end{array}$ \\
\hline $\begin{array}{l}\text { Symptom } \\
\text { relief }\end{array}$ & $\begin{array}{l}\text { Continue } \\
\text { but possibly } \\
\text { adjust the } \\
\text { dose }\end{array}$ & $\begin{array}{l}\text { Evaluate, for } \\
\text { example, by } \\
\text { treatment } \\
\text { interruption }\end{array}$ & $\begin{array}{l}\text { Terminate } \\
\text { direct/phase } \\
\text { out. } \\
\text { Try new } \\
\text { treatment. }\end{array}$ \\
\hline Preventive & $\begin{array}{l}\text { Continue } \\
\text { but possibly } \\
\text { adjust the } \\
\text { dose }\end{array}$ & $\begin{array}{l}\text { Seek better } \\
\text { options }\end{array}$ & $\begin{array}{l}\text { Terminate } \\
\text { direct/phase } \\
\text { out. } \\
\text { Consider } \\
\text { other } \\
\text { treatment. }\end{array}$ \\
\hline $\begin{array}{l}\text { Doubtful } \\
\text { or not } \\
\text { approved } \\
\text { treatment }\end{array}$ & $\begin{array}{l}\text { Consider } \\
\text { other } \\
\text { treatment } \\
\text { or continue } \\
\text { if strong } \\
\text { reason exist }\end{array}$ & $\begin{array}{l}\text { Seek better } \\
\text { options with } \\
\text { approved } \\
\text { indication }\end{array}$ & $\begin{array}{l}\text { Terminate } \\
\text { direct/phase } \\
\text { out. } \\
\text { Try possibly } \\
\text { new } \\
\text { treatment. }\end{array}$ \\
\hline
\end{tabular}

reuptake inhibitors, benzodiazepines, opioids and sedatives. ${ }^{1}$

A clinical pharmacist should be able to assess this type of risk based on the therapeutic, pharmacokinetic and pharmacodynamic considerations and make a decision if the drug can be deprescribed immediately or whether it should be withdrawn slowly. The Swedish National Board of Health and Welfare have decided that medication review be performed annually and for example, at hospitalisation for all patients over 75 years and with at least five drugs. A clinical pharmacist should be part of the team including the responsible physician and nurse. To support the review, national targets for comparisons and support for more rational drug therapy have been established. To support safe deprescribing, 14 drug and therapeutic committees in Sweden have over a number of years prepared a document on how to practically, safely and gently withdraw older patients' drug therapy. This documentation has been compiled into a book ${ }^{1}$ focusing on 36 different drug groups with detailed instructions when slow withdrawal is warranted. This project and compilation of reference data seems unique.

The January issue of $E J H P^{2}$ focused on deprescribing as a method. Several papers present and describe different aspects and approaches to the subject. Interestingly, no paper focuses on which medication needs slow withdrawal based on the aspects presented above and which is the focus in the Swedish project. ${ }^{1}$ According to the author there is a plan to publish a fourth edition with more chapters and also translated to German. If there is interest there might be an English translation. The authors of the themed issue and I are only aware of one more approach in this direction but it has limited information. ${ }^{3}$

There is a need for well-educated, skilled pharmacists to lead the clinical team in managing inappropriate polypharmacy and deprescribing. I hope that this editorial together with the themed issue can stimulate all of these aspects and also publications in our journal.

\section{EAHP Statement 6: Education and}

Research

Competing interests None declared.

Provenance and peer review Not commissioned; internally peer reviewed.

(C) European Association of Hospital Pharmacists (unless otherwise stated in the text of the article) 2017. All rights reserved. No commercial use is permitted unless otherwise expressly granted.

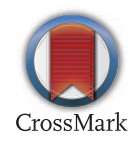

To cite Eriksson T. Eur J Hosp Pharm 2017;24:137.

Published Online First 6 April 2017

Eur J Hosp Pharm 2017;24:137.

doi:10.1136/ejhpharm-2017-001265

\section{REFERENCES}

1 Lundgren C. Fas-ut 3: att utvärdera, ifrågasätta och skonsamt avsluta läkemedelsbehandling [Phase out 3: to evaluate, question and gentle terminate drug treatment]. 3rd edn. Umeå, Sweden: Tryckeri City, 2010. ISBN 978-91-633-7637-5 (in Swedish).

2 Barnett N, Jubraj B. A themed journal issue on deprescribing. Eur J Hosp Pharm 2017;24:1-72.

3 A practical guide to stopping medicines in older people. Best Practice Journal 2010;27:11-23. http:// www.bpac.org.nz/BPJ/2010/April/stopguide.aspx. 